Р. В. Лопатич

\title{
СИСТЕМА ВПРАВ ДЛЯ РОЗВИТКУ ЛОГІЧНОЇ КУЛЬТУРИ НА ЗАНЯТТЯХ ІНОЗЕМНОЇ МОВИ
}

Лопатич Р. В. Система вправ для розвитку логічної культури на заняттях іноземної мови.

У статті розглянуто типи вправ для формування мовленнєвої компетенції; запропоновано систему вправ, послідовне виконання яких сприяє розвитку логічної культури на заняттях іноземної мови.

Ключові слова: логічна культура, вправа, вправи на розвиток логічного мислення та логічного мовлення, аналітичні вправи.

Лопатич Р. В. Система упражнений для развития логической культуры на занятиях иностранного языка.

В статье рассматриваются типы упражнений для формирования речевой компетенции; предлагается система упражнений, выполнение которых способствует развитию логической культуры на занятиях иностранного языка.

() Р. В. Лопатич, 2015. 
Ключевые слова: логическая культура, упражнение, упражнения на развитие логического мышления и логической речи, аналитические упражнения.

Lopatich R. W. The system of exercises for development of logical culture on foreign language lessons.

The article describes a set of exercises in forming of the speech competence, gives the system of exercises. When implemented sequentially in a class, the exercises will help develop logical culture on the lessons of foreign language.

Key words: logical culture, exercises on development of the logical thinking and logical speech, analytical exercises.

Сучасні зміни в політичному та економічному розвитку суспільства, орієнтація на загальноєвропейські рекомендації та вимоги до вивчення іноземної мови суттєво вплинули на систему іншомовної освіти в Україні. Нова роль іноземної мови як засобу міжкультурного спілкування спричинила зміщення акцентів у змісті фахової підготовки. Майбутній учитель іноземної мови повинен не тільки оволодіти словесним кодом певної мови, але й уміти використовувати на практиці отриману 3 іншомовних джерел інформацію, узагальнювати й аналізувати їі. Оскільки вчитель іноземної мови має безпосереднє відношення до розвитку логічного мислення учнів, формування в них навичок логічного викладу думок та зв'язного мовлення, він повинен володіти логічною культурою. Тому задля забезпечення якісної професійної підготовки слід приділяти належну увагу проблемі формування логічної культури майбутніх учителів іноземної мови. Зважаючи на це, важливо ще під час навчання у вищій школі сформувати в майбутніх спеціалістів високий рівень логічної культури, що є одним зі складників його фаховості.

Аналіз філософської, психолого-педагогічної та методичної літератури засвідчує, що проблемі формування логічної культури присвячено чимало публікацій. Так, методологічні засади формування логічної культури досліджували О. Баринова, С. Баширова, В. Бочаров, В. Брюшинкін, А. Гетьманова, В. Журавльов, Є. Іванов, Ю. Івлєв, Г. Лаврешина, О. Лазаревич, С. Марценюк, Н. Мойсеюк, В. Свінцов, В. Сухомлинський, Л. Тихомирова, О. Тихомирова, М. Тофтул, Л. Фаткуллова, О. Франчук, О. Халабузар, О. Яковлєва. Окремі аспекти засвоєння знань шляхом міркувань відображено в дослідженнях представників німецької школи іншомовної освіти П. Біммеля (P. Bimmel), Ф. ван дер Верф (F. van der Werff), Й. Гербеса 
(J. Gerbes), У. Гревера (U. Grewer), С. Дінзель (S. Dinsel), М. Крюгера (M. Krüger), Г. Нойнера (G. Neuner), М. Райманн (M. Reimann), У. Рампіллон (U. Rampillon). У методиці викладання іноземних мов достатньо опрацьована система вправ задля формування мовленнєвої компетенції (В. Бухбиндер, Г. Городілова, 3. Ієвлева, Є. Пассов). Але незважаючи на це, залишається відкритим питання створення системи вправ для формування та розвитку логічної культури на заняттях іноземної мови.

Мета статті полягає в тому, щоб дослідити процес формування логічної культури на заняттях іноземної мови. У зв'язку з цим ми ставимо перед собою завдання визначити й обгрунтувати систему вправ, спрямованих на формування логічних умінь та розвиток логічного мислення.

Спираючись на аналіз наукових праць філософів та педагогів, розглядаємо логічну культуру як складне особистісне новоутворення, що входить до складу навчальної компетентності і передбачає здатність особистості здійснювати різні розумові операції (класифікувати, формулювати визначення, узагальнювати, доводити, аналізувати, робити висновки тощо), які забезпечуються знанням законів логіки та вмінням використовувати їх у різних контекстах (під час пошуку, обробки та презентації нової інформації іноземною мовою або для реалізації певної комунікативної мети), контролювати логічну побудову речень із урахуванням причинно-наслідкових зв'язків, а також здатність студентів усвідомлювати логіку засвоєного матеріалу та самостійно організовувати навчальний процес за умов їхньої високої розумової активності.

У фаховій підготовці майбутніх учителів іноземної мови значна частина аудиторної навчальної роботи відводиться лабораторним заняттям з іноземної мови. Тому задля формування логічної культури ми застосовували спеціально розроблений комплекс вправ, у якому велика увага приділялася вибору завдань, спрямованих на активізацію мисленнєвої діяльності, підвищення пізнавальної активності студентів, оволодіння навчальними стратегіями, реалізацію отриманих знань на практиці, формування професійних умінь, необхідних для практичної діяльності тощо. Як відомо, вправа - це спеціально організоване в навчальних умовах багаторазове виконання окремих операцій, дій або діяльності задля оволодіння ними або їх удосконалення [1, с. 64]. У рамках комунікативного підходу при навчанні іноземної мови ( Р. В. Лопатич, 2015. 
виділяють такі типи вправ, як-от: комунікативні (мовленнєві), умовнокомунікативні (умовно-мовленнєві) і некомунікативні (мовні) $[1 ; 2 ; 4]$. Комунікативні вправи передбачають створення таких умов на занятті, коли студент постійно залучений до процесу практичного користування мовою в різних видах мовленнєвої діяльності. В умовнокомунікативних вправах передбачаються мовленнєві дії студентів у ситуативних умовах [1, с. 66]. До умовно-мовленнєвих вправ Ю. Пассов зараховує переказ, опис, вираження свого ставлення, оцінки. При виконанні цих вправ необхідно формулювати установки так, щоб вони спонукали людину висловитися у процесі реального спілкування. У некомунікативних або мовних вправах виконуються дії 3 мовним матеріалом поза ситуацією мовлення, зосереджуючи увагу лише на формі, i тому Ю. Пассов диференціює такі види мовних вправ: перекладні, трансформаційні вправи та підстановчі вправи [2]. У навчанні іноземної мови А. Чистякова виокремлює мовні, лексичні та мовленнєві вправи [3, с. 209-210]. Мовні вправи, на думку дослідниці, повинні безпосередньо та максимально переслідувати вузьку, окреслену викладачем мету, наприклад, навчити розпізнавати різні морфологічні показники. Лексичні вправи спрямовані на формування навичок правильного вживання лексики в усній та письмовій формах. Мовленнєві вправи містять такі види діяльності: переказ (прочитаного та прослуханого, вибірковий переказ, переказ за планом, за допомогою ключових слів тощо); повідомлення на соціально-побутові теми; опис (ситуацій, малюнків); розповідь (про себе, про те, що прочитав, 3 опорою на кіно- або відеофільми тощо).

При виборі вправ, спрямованих на формування логічної культури, керувалися концептуальними положеннями комунікативного підходу. Більшість науковців (Н. Бабич, Н. Волкова, М. Пентилюк, О. Павленко, Г. Сагач та ін.) зазначає, що без здатності мислити неможливо чітко сформулювати свою думку, та наголошує на тому, що розвиток комунікативних навичок тісно пов'язаний із формуванням навичок мислення. Логічне мовлення формується на основі навичок логічного мислення, знання мовних засобів і логіки викладу матеріалу, тому у процесі вивчення іноземної мови слід це враховувати і навчити студента правильно оформляти своє висловлювання з позиції підбору лексичних засобів, граматичної структури та водночас розвивати в нього логічне мислення, уміння послідовно і переконливо доводити 
свою думку іноземною мовою.

Аналіз наукових робіт засвідчує, що при вивченні іноземної мови, при навчанні іншомовного мовлення мислення стимулює розвиток здібностей студента до аналізу, дедукції, аргументації. Деякі дослідники (О. Ястребова, А. Есаулов) стверджують, що ті студенти, які вже володіють умінням виокремлювати головне та чітко формулювати свої думки, швидше адаптуються до своєї майбутньої професійної діяльності [5; 6]. Відтак, зважаючи на тісний зв'язок мовлення та мислення, а саме на те, що логічне мислення впливає на розвиток логічного мовлення, вважаємо за доцільне застосовувати на заняттях іноземної мови вправи, які спрямовані на розвиток у студентів логічних умінь (виокремлювати головне, ставити запитання, дати визначення відомого поняття), навичок мислення (аналіз, порівняння, класифікація, узагальнення). Крім того, застосовуючи систему вправ, прагнемо навчити студентів володіти необхідними для навчання та їх подальшої професійної діяльності практичними навичками й уміннями, а саме: при роботі 3 іншомовним текстом, при роботі з таблицями, графіками, при підготовці до проекту, дискусії тощо. Отже, задля розвитку логічної культури виділяємо підготовчі вправи, вправи на розвиток логічного мислення й мовлення та аналітичні вправи.

1. Підготовчі вправи спрямовані на розвиток уміння формувати фрази та поєднувати їх між собою відповідно до логіки висловлювання. Ці вправи розраховані саме на те, аби навчити студентів концентруватися на важливій ключовій інформації. Відповідно до мети навчання студентам пропонують пошукові вправи, зорієнтовані на формування та відпрацювання навичок пошуку й передачі інформаціі, що сприяють розвитку логічних умінь і стимулюють розумову активність студентів. Щоб навчити студентів концентруватися на важливій ключовій інформацї̈, ми використовували метод ключових слів (Schlüsselwörter), метод нотаток (Notizen), метод 3'єднання ключових слів стрілочками (Flussdiagramm), методи глобального, вибіркового та детального читання (globales Leseverstehen, selektives Leseverstehen, detailliertes Leseverstehen) [7; 8; 9]. Проілюстуємо приклади таких вправ:

a) Was kann man kaufen? Sammeln Sie die Lexik zum Thema.

Lebensmittel: Brot, Eier, ..., ...,...

Kleidung: Kleider, ..., ..., ...

() Р. В. Лопатич, 2015. 
б) Lesen Sie ein Interview. Anhand des Interviews sammeln Sie die Schlüsselwörter zu den Themen:

\begin{tabular}{|c|c|}
\hline Computer beim Studium & Computer als Zeitvertreib \\
\hline & \\
\hline
\end{tabular}

B) Sagen Sie mit einem Wort.

Tastatur, Maus, einspeichern, Datei...

Glück, Ärger, Ruhe, Freude, ...

Staubsaugen, waschen, putzen, bügeln, ...

2. Вправи для розвитку логічного мислення та мовлення, виконання яких сприяє формуванню навичок логічного мислення, розвитку логічного мовлення, умінню використовувати набуті навички на практиці. Прикладами вправ, спрямованих на формування вміння узагальнювати, порівнювати, є такі:

a) Was passt nicht in die Reihe? Warum? Wie kann man diese Lebensmittel mit einem Wort nennen?

Butter - Käse - Wurst - Milch - Joghurt

Apfelsine - Apfel - Birne - Brezel - Kirsche

Mineralwasser - Cola - Limonade - Ö1 - Saft

б) Ersetzen Sie diese Äußerungen durch Synonymwendungen.

Er hat festen Charakter.

Sie nimmt auf die anderen Menschen immer Rücksicht.

Er steht mit vielen Menschen auf freundschaftlichem Fuße.

в) Vergleichen Sie die Menschen mit den Tieren.

Beispiel: schlau wie ein Fuchs

$\begin{array}{ll}\text { langsam } & \text { ein Wolf } \\ \text { hungrig } & \text { ein Bär } \\ \text { sanft } & \text { ein Hahn / Pfau }\end{array}$

До вправ на розвиток логічного мислення та мовлення належать також комплекси смислових висловлювань (mind map), вправи на вміння ставити запитання, робота 3 картинками, використання асоціаграм. Вони спрямовані на формування таких умінь: уміння витлумачити відоме поняття, уміння порівнювати, узагальнювати, аналізувати тощо. Застосовані на заняттях іноземної мови стратегії виправдовують себе на практиці, адже активізують мисленнєвомовленнєву діяльність студентів, тренують їхню пам'ять.

3. Аналітичні вправи, спрямовані на формування всіх компонентів логічної культури, а саме вміння визначати предмет своєї думки, давати 
дефініцію відомого поняття, формулювати запитання та відповідати на них; уміння виокремлювати основне, порівнювати, аргументувати, робити висновки тощо. Виконання таких завдань спонукають студентів до самостійного, логічного осмислення навчального матеріалу і тим самим підвищують їхню розумову активність. Наприклад:

a) Fassen Sie den Sinn mit einem Wort.

Wie ist der Mensch, der ...

alles wissen will?

stets etwas vergisst?

viel Geld ausgibt?

б) Erklären Sie:

Der schadenfrohe Mensch ist der Mensch, der .......

Der zuverlässige Mensch ist der Mensch, der....... .

Der selbstlose Mensch ist der Mensch, der ......

в) Verwenden Sie folgende Wendungen in sinnvollen Situationen.

Er hält die Zunge im Zaune.

Er sieht alles durch eine rosarote Brille.

Ihn stört sogar die Fliege an der Wand.

Запрпонована система вправ активізуватиме мисленнєву діяльність студентів, розвиватиме їхні логічні вміння та сприятиме застосуванню логічних операцій під час виконання завдань.

Отже, через упровадження системи вправ на заняттях іноземної мови розвивається логічна культура студентів. Слід робити акцент на застосуванні у змісті навчання іноземної мови завдань на розвиток логічного мислення й мовлення, розв'язанні проблемних і створенні комунікативних ситуацій. Застосування системи вправ для розвитку логічної культури сприяє розвитку логічних умінь і вдосконаленню навичок мислення, підвищенню рівня культури мовлення, що знаходить своє відображення в умінні чітко, логічно й послідовно висловлюватися іноземною мовою, ставити запитання, давати грунтовні відповіді, аналізувати та робити висновки, що впливає на успішність студентів.

\section{Література}

1. Методика навчання іноземних мов у середніх навчальних закладах : [підручник] / С. Ю. Ніколаєва, О.Б. Бігич, Н.О. Бражник та ін. ; під ред. С. Ю. Ніколаєвої. - [2-е вид, випр. і перероб.]. - К. : Ленвіт, 2002. -328 с.

2. Пассов Е. И. Коммуникативный метод обучения иноязычному говорению / 
Е. И. Пассов.- М. : Просвещение, 1991. - 223 с.

3. Чистякова А. Б. Система вправ при навчанні іноземної мови [Електронний pecypc] / А. Б. Чистякова. - Режим доступу : http://www.readera.org/article/syestemavprav-prye-navchanni-inozemnoye-movye-10156180.html.

4. Шатилов С. Ф. Методика обучения немецкому языку в средней школе : [учебное пособие] / С. Ф. Шатилов. - [2-е изд., дораб.]. - М. : Просвещение, 1986. - 223 с.

5. Эсаулов А. Ф. Активизация учебно-познавательной деятельности студентов : [науч.-методическое пособие] / А. Ф. Эсаулов. - М. : Высшая школа, 1982. - 223 с.

6. Ястребова Е. Б. Развитие познавательной самостоятельности студентов младших курсов вуза / Е. Б. Ястребова // Советская педагогика. - 1982. - № 11. - С. 75-77.

7. Bimmel P. Lernautonomie und Lernstrategien / P. Bimmel, U. Rampilion. München : Langenscheidt, 2000. - 208 S.

8. Dinsel S. Fit fürs Zertifikat Deutsch (Tipps und Übungen) / S. Dinsel, M. Reimann. Hueber Verlag, 2009. - $118 \mathrm{~S}$.

9. Neuner G. Übungstypologie zum kommunikativen Deutschunterricht / G. Neuner, M. Krüger, U. Grewer. - Berlin : Langenscheidt, 2000. - 184 S.

Стаття надійшла до редакиії 07.04.2015 p. 